\title{
Financing urban transport through value capture
}

\author{
Lucía Mejía Dorantes $^{1}$, José Manuel Vassallo Magro² \\ ${ }^{1}$ TRANSyT -Universidad Politécnica de Madrid, Spain, \\ ${ }^{2}$ Universidad Politécnica de Madrid, Spain
}

\begin{abstract}
The Green Paper on Urban Transport highlights the importance of promoting public transport as a means of achieving better sustainable mobility. Unfortunately, budget resources are often constrained. On the other hand, literature points out that transport infrastructure induce economic impacts in the areas where they are placed. This effect is caused by the fact that people realize the positive effects of accessibility and want to live or work close to transport stations.

Regarding this fact a question arises. Is it possible to capture the value induced by the construction of a new infrastructure facility as an additional financial source? The aim of this paper is to analyze different direct and indirect mechanisms of value capture to fund transport infrastructure.
\end{abstract}

\section{Introduction}

The European Union in the Green Book on Urban Transport notices that in order to foster urban and suburban sustainable mobility among citizens, they should be provided with transport services with quality, that are efficient and reliable. However, to provide good services, it is essential to develop and adequately maintain and operate the necessary infrastructure facilities. The report intends to establish different strategies for sustainable urban transport, giving special emphasis in the need to rely on important economical resources to invest in transport infrastructure. Those strategies take shape in a group of measures related to budgets, regulations and dif- 
ferent financial instruments such as specific local taxes, in order to accomplish the goals.

On the other hand, urban economics states that if a property has the opportunity to access to better benefits than the others, the demand for it will be higher, increasing its value.

A new station generates a benefit around it, which people living or working close to it take special advantage from. This benefit is noticed in the real estate market increase, especially in the areas close to the stations. The above is because people prefer to live close to a public transport station that will facilitate their commuting trips and lower their transportation costs. Likewise, retail stores and offices are benefited in its location by the number of people that uses this means of transport and by the facility that means of transport implies to the employees to commute.

It is convenient to comment that in some cases negative externalities are produced around the buildings close to the transport lines. It is important to differentiate between the externalities produced by being close to a station and the ones produced by being close to the transport line, especially when the line is at ground level. The negative externalities are produced principally by noise, vibrations and landscape affection, but nowadays due to new materials and new technology, these negative effects can be minimized and are topics taken into account when designing the infrastructure.

If the benefits produced by the infrastructure exist and can be accounted, it is necessary to question to whom theses benefits belong to. It is true that a new transport line provide a general benefit to the neighborhood but especially to the closest buildings. This value capture could be used to fund part of the transport infrastructure construction, operation or maintenance in order to diminish the contribution of public resources.

In the following part, some mechanisms used in different places are presented, that contribute to transport infrastructure funding.

\section{Case studies}

There are many examples of value-capture due to a transport infrastructure. We discuss some of them in the following paragraphs.

\section{Los Angeles, California}

To repay construction costs of the Los Angeles Metro Red Line, private businesses located $1 / 2$ or $1 / 3$ mile close to the station, contribute by an assessment rate. This rate takes into account the benefited area, plus the last three years' delinquency rates. Furthermore, the price is fixed, therefore 
properties, independently of the type of business, pay the same for each square meter. It was a very long process to establish this mechanism, faced a lot of resistance but nowadays this rate is equal to the $9 \%$ total investment cost of this line [1].

\section{France}

This country has established a public transport funding system known as "Versement Transport (VT)". It is a specific tax paid by public or private companies with more than 9 workers, located within a 10000 habitant's urban transport perimeter. This tax is used to fund either operational costs or new transport infrastructure. The Urban Transport Authorities (AOTU) are in charge of establishing this tax as well as the rate, with a maximum contemplated by the law [2].

The VT represents around the 33\% from all the urban transport's operational and investment costs without taking into account the Paris region. In this region, the companies also contribute with the $50 \%$ of the monthly ticket of their employees, therefore, the companies' final contribution increases to the $43 \%$ [3]. Hence, this tax is the main permanent funding source that allows vehicle modernization, to have new infrastructures been built and other operational costs.

\section{Munich, Germany}

The mechanism used is based on the interest of the urban developer. If he is interested in obtaining the license to construct a neighbourhood, first he has to obtain the land value from a real estate experts' panel. After the land has the license and it has started to being constructed, the land value will increase. The difference between those two values is a measure that local authorities may claim, even till $2 / 3$ parts of this difference, as a source to construct public infrastructure. The rest of the value corresponds to the land developer [4].

\section{Hong Kong}

The train system in Hong Kong is known for its high quality and by its self-financing mechanisms without using public resources. To achieve so, they have implemented different mechanisms such as the "RailwayProperty Development Model”. This model gives the rail companies the right to build urban developments around the stations or even underneath or over the stations [5]. This mechanism allows maximizing the urban use 
around stations. Therefore, people could access very easily to the transport system and much more properties are benefited by the transport service.

The above implies that urban developments work as financial organisms of transport projects.

This kind of financial schemes have been used to develop 6 millions $\mathrm{m}^{2}$ of housing and 5 millions $\mathrm{m}^{2}$ of office and retail areas [5]. That explains in part their self-financing transport system.

\section{Spanish situation}

\section{Taxes and tributes}

In the next paragraphs there are briefly explained the most important property taxes as well as the Special Contribution tribute case.

\section{Property Tax (IBI)}

This tax is paid once a year; the value is established and paid to the city council as a percentage of the properties official value.

\section{Urban land value increase tax}

It has to be paid by whoever sells urban land, house, apartment, parking space, etc. for the land value increase it has got while being proprietary. Nonetheless, this tax does not take into account the reason of that value increase and its objective is not exactly to contribute to public transport funding.

The taxes above, like all taxes in Spain, are not earmarked. On the other hand, there are as well other mechanisms to collect funds, such as fees and special contribution that may have self-financing purposes.

\section{Special contributions}

The Spanish law contemplates this tribute as "those tributes where the taxable event consists in obtaining by the party who executes the event, a benefit or a value increase in his properties, as a consequence either of public works, or establishment or extension of public services" [6]. The Highways Law contemplates this financial mechanism as well, either for physical persons or with corporate identity that become especially benefited by the property value increase due to the public works carried out. 
The problem is how to justify this benefit, the benefit amount and the impact area. The above has made this tribute difficult to put into practice.

\section{Spanish experiences}

Special contributions are covered in the legislation; however, most of the times are not used because it might take a long legal process. Nevertheless, there is an initiative to start using them. For example; Parla's light rail, where the city council invested 87 million euros to finance it. They look forward to recovering part of the investment by special contributions from private housing developers, around 10\% of the invested [7].

Other simpler schemes have been put into practice, to fund transport infrastructures, most of the times through negotiations with developers. This is the case, long time ago, of the "Cuatro Caminos" metro station in Madrid. The transport company built a new neighborhood in order to collect money to construct the infrastructure. The same happened years latter with line 1 expansion in the "Ensanche de Vallecas" zone where 37\% of tunnel total costs were paid by urban developers using the increase in property values generated to those properties close to the stations, approximately, 25 millions euro.

Another interesting example is the metro line known as Metronorte, where the company "Telefonica" has funded part of the line to get to their new offices, in "Las Tablas" neighborhood, called "Ronda de la Comunicación". Through an agreement with the state government, the company contributed with 9 millions euros to build the new station plus 5 millions to construct the metro tunnel that crosses the building, around 260 meters long.

\section{Proposals for Spain}

\section{Developer's fee}

The simplest way to achieve value-capture, it saves time and it is based in looking for Transport Oriented Development (TOD) projects since the very beginning. It is recommended to legislate in this matter and specially to apply the existent mechanisms, like special contributions. If the developers are demanded to build part of the transport infrastructures, that will definitely improve the quality of the area, therefore increasing the benefits of the buildings, this implies a higher sale's price. It would have a high ac- 
ceptability because society would not perceive this charge, it could be said that this is a win-win strategy.

It is a measure that has already been applied, either to developers or companies; however, until now it has depended on the good will of the benefited parts to contribute to the construction. As an example we have Telefonica Company in Metronorte facing the situation of "La ciudad financiera" of the Bank SCH, that did not have the willingness to contribute to the light rail construction so it could reach their new offices in order to benefit their 5000 workers to encourage the use of public transport, in contrast, they built a parking lot for 3500 places.

The main problem is that this scheme could be used to new housing developments but not in existent neighborhoods even though new transport infrastructure would be provided, for these cases additional mechanisms should be established.

\section{A modification to the urban land increase value tax}

This tax is established by the city council and they are the ones that manage it. The law says that the tax rate is based on the value increase between the value when the property was bought and the sale's price with a $30 \%$ maximum. Nonetheless, the collected taxes go to the general budget resources; hence it is impossible to differentiate which part belongs to transport value-capture.

It is proposed that an infrastructure fund is established by the city councils in order to capture the tax's proportional part due to transport infrastructure.

This is a very simple solution that would have neither acceptability, nor collecting problems. The main problem is that it has to be fulfilled that the city councils spend these funds only for public transit. It should be legislated in order to achieve this matter.

\section{Office and retail fee}

If retail and business centers are well communicated through different means of transport, the landlord as well as the tenant are benefited by the opportunities they have. Therefore, they should be asked to contribute to the infrastructure.

For that sake it is proposed to establish a fee where the companies or stores settled within a perimeter of 1000 meters from the transport station contribute to the transport infrastructure's operational costs or exchanging it by their employees' monthly transport ticket $(100 \%$ or $50 \%$ of it). It would have a very good social acceptability because the fee would not be 
paid directly by the society and the companies located close to stations would receive a better amount of clients, they would contribute to improve the environmental quality of the cities, they would also diminish their employees' transportation costs, promoting the use of sustainable transport and improving their corporate image. Likewise, the benefits captured by this measure would be transferred directly to the transport authority and thereby they would be directly reinvested only in transport infrastructure.

In Madrid some private and public companies already offer this incentive, for example the Transport Administration in Madrid, most of the public administrations in Madrid city and in the region of Madrid as well, that provide to their employees the annual transport ticket. Some national ministries and public organisms like the Universidad Complutense give this incentive.

Finally, very few private companies provide this incentive, around five or ten and most of them are small companies.

\section{Private transport fee}

A similar measure has been proposed in London, Sydney and Perth, but through taxes to parking lots in business centers. These types of initiatives are very questioned although they may raise an important amount of money as well as may diminish the use of private transport.

It is proposed that if people that live in an area benefited by public transport still prefer to use private transport (at least that their condition turns it to be indispensable), they should be penalized through a private vehicle fee registered in that property. The objective is to reduce the number of cars per family, improving each home's mobility.

It seems to be a very complicated measure to establish because it has to be defined a border between the zones that are benefited by public transport from the ones that are not. It seems to be a measure with low social acceptability. Nevertheless, it would diminish each family's number of vehicles as well as promoting either public transport or a better mobility culture. Finally, it would induce people's relocation by their means of transport. Those who prefer private transport would move towards areas where this fee has not to be paid, giving priority to live close to the stations to the people that prefer to use public transport.

\section{Conclusions}

Nowadays, it can be said that value capture has not been taken advantage of to fund transport infrastructure. In order to achieve the goals set by the 
EU in the Urban Transport Green Paper, it is necessary to propose new financial mechanisms to reinvest in public transport projects in such a way that justice, feasibility and social acceptability are accomplished.

On the other hand, it is necessary to adapt the current fiscal system to capture the benefits produced by the transport infrastructures to use them to fund and maintain these infrastructures. Likewise, an effort should be made to apply the existent measures, especially those related to special contributions in Spain.

The presented proposals intend to promote the use of public transport as well as to penalize the use of private transport in areas close to train or metro stations, in order to promote that people that work or live close to the stations change to public transport.

It is important to notice the importance of urban densification especially in the closest zones to stations to attract as much people as possible to fulfill the optimum operational standards, where value-capture measures would be best exploited.

\section{References}

1. Rolon A (2008) An evaluation of value capture mechanisms from linkage capture to special assessment districts. Transportation Research Board, Annual Meeting. January 13-17, 2008. Cambridge Systematics, San Francisco, CA

2. Pascal V (2003) Les transports publics urbains en France. CERTU. Direction des transports terrestres. France. 2003

3. Varnaison Revolle P (2008) Le financement des transports publics urbains en France. Séminaire Régional sur les Déplacements Urbains en Méditerranée. Skhirat, Maroc. 22-23 janvier 2008

4. Hass-Klau C (2006) Capture of land value premiums as a source of funding for public transport: Evidence and practice in selected European metropolitan areas. EMTA Association. Final report March 2006

5. Jain A (2007). Railways-A catalyst for urban development in Hong Kong. Public Transport International No.5, pp. 17-19

6. Ballesteros A, Castelao J, Santos C (2003) Diccionario Enciclopédico El consultor. Diccionario Jurídico de Administración Local. Tomo I. $2^{\text {a }}$ edición. El Consultor de los Ayuntamientos y los Juzgados. Madrid, Span

7. Delgado L (2007) Learning from Parla Tramway Experience. Transurban project Workshop. Cambridge, April 16-17, 2007 